\title{
Transportation of Food by Cold Chain Methods one of the Cause of Reoccurrence Covid-19 Infection during its Pandemic
}

\author{
Mesut Selamoğlu, ${ }^{1, a}$, Ali Raza Memon ${ }^{2, b, *}$ \\ ${ }^{I}$ Department of Management \& Organization Logistics Programme, Bache Vocational School, Osmaniye Korkut Ata University, 80000 \\ Osmaniye, Turkey \\ ${ }^{2}$ Department of Biochemistry, Liaquat University of Medical \& Health Sciences (LUMHS) Jamshoro, Sindh, Pakistan \\ *Corresponding author

\begin{tabular}{l|l} 
A R T I C L E I N F O & A B S T R A C T \\
\hline Review Article & $\begin{array}{l}\text { The Corona Virus is the pandemic all over the world. This viral infection attacked all over the world } \\
\text { like as disaster of viral infection which causes morbidity and mortality in different regions of world } \\
\text { like Asia, Europe, and Africa etc. The different countries control the spread and complications of } \\
\text { covid-19 like Acute Respiratory Distress Syndrome in well manner. In second wave there was again } \\
\text { out break of covid-19 some regions of world. Here we discuss the causes of reoccurrence and their } \\
\text { preventive measurements from our break effects of Covid-19. }\end{array}$ \\
$\begin{array}{l}\text { Received : 06/11/2021 } \\
\text { Accepted : } 12 / 11 / 2021\end{array}$
\end{tabular} \\ Accepted : 12/11/202
}

\author{
Keywords: \\ Cold Chain \\ Covid-19 \\ Food \\ Pandemic \\ Transportation
}

\section{Introduction}

Corona virus disease (Covid-19) is the global disaster all over the world in year 2019 to 2021 (Buttell and Ferreira, 2020). According to W.H.O report the 196 million peoples diagnosed as Covid-19 cases and more than 4 millions people was died due to this viral disaster in 2019 and 2020 (Khan et al., 2020). There is emergency need to stop the spread this viral infection but there is risk still present due to local out break.

The primary route for spread of Covid-19 infection is person-to-person contact due to droplet infection received via respiratory route from infected person (Angelos et al., 2020). But during pandemic of Severe Acute Respiratory Syndrome (SARS CoV-2) we cannot inattention that this infection can spread through transportation of frozen food from one place to other place with wide range. Before the formulation of SARS-CoV-2 identification tools health departments and authorities not seriously intention in this mode of transmission. The transmission of Covid-19 infection via food transmission is called as "fame to table cycle" in which infection also transmit via respiratory droplet but during the farming, processing, storage, transport, packing etc food may get carrier of viral infection from infected person (Olaimat et al., 2020; Shahbaz et al., 2020). The breathing, coughing, sneezing of the infected person of Covid-19 may contaminated the food during packing and storage and also contaminates the material in which food has been stored and packed (Shahbaz et al., 2020). These findings suggested that Covid-19 can survive on cold chain foods during their packing transportation process from shipping for long distances. In the China health department and researchers also postulated that transportation of huge amount of refrigerated foods from one region to another region of country is one of the cause of spreading as well as reoccurrence of Covid-19 infection (Han et al., 2021; Pang et al., 2021). 


\section{Discussion}

Covid-19 pandemic is still alarming health destruction sign at different regions of world at Asia, Europe countries. More than 60 countries are reported as mutated SARS$\mathrm{CoV}-19$. There was discussion at different forum all over the world regarding out breaks of Covid-19 (Cappelli and Cini, 2020; Deaton, 2020; Ali et al., 2021).

In the pandemic of Covid-19, food safety is the main tool among the four pillars of food system. Up to December 2019 there was lot of studies reported the out break of Covid-19 associated with food industry (Galanakis, 2020; Rizou et al., 2020).

Rizou et all in the begging of 2020 they believed that there is negligible role of food transmission in out breaks of Covid-19. But Sharma et al in 2020 postulated cold chain food transmission is one of the potential risk factor of Covid-19 infection (Rizou et al., 2020).

Love et al in 2021 also reported the positive correlation of Covid-19 transmission in sea food in early five months of 2021 . He reported that there were vulnerable effects in out break of this infection in certain group of workers (Love et al., 2021).

Han et al in 2021 reported that there is no strong transmission of Covid-19 via food and water (Han et al., 2021).

It was proposed that SARS CoV-2 virus highly stable at $4{ }^{\circ} \mathrm{C}$ in laboratory environment and fish, meat other food items has been stored and transported with temperature of $-10^{\circ} \mathrm{C}$ to $-80^{\circ} \mathrm{C}$ for 14 to 21 days, at this temperature Covid-19 can alive easily (Selamoglu, 2021).

Lieu et al in 2020 reported that there was reoccurrence of Covid-19 at the destination areas via food transportation by cold chains (Liu et al., 2020).

We find the studies regarding possible transmission of infection of Covid-19 from objects to man kind but there is no any study found on cold chain food supply with their accurate route of transmission of Covid-19.

So there is imperative need to research on transmission routes of SARS-CoV-2 and sources of reoccurrence of Covid-19 infection with their safety measurements for the prevention of localized epidemic out break by transportation of food supply by cold chain at any time.

\section{Conclusion}

Recurrent outbreak in China has proved that the imported cold food supply chain is one of the most important ways for the outbreak and spread of COVID-19. The contaminated cold food or food packaging material can transmit the virus, and an infected worker will spread the virus through "person-to-thing-to person" transmission not just through "person-to-person", which is different from the previous reports. Therefore, formulating a comprehensive prevention plan to deal with the localized outbreak epidemic at any time should be considered as a priority for public authorities. The COVID-19 pandemic has urged world nations enforced rapid and sometimes very contradictory policies to limit the virus spread, with results ranging widely from total failure to moderate success (Ufnalska and Lichtfouse 2021). The international community should pay close attention to SARS-CoV-2 transmission mode through cold chain, build international cooperative efforts in response, share relevant data, and call on all countries to take effective prevention and control measures to prevent virus contamination in cold chain food production, marine fishing and processing, transportation and other operations. Overall, no country can be locked down for a long time and independent from the rest of world. As long as it has economic exchanges with other countries, it will face the safety risk of imported epidemic. This study will be helpful for other countries to control the spread of COVID-19, open up economy and return to normal life as soon as possible.

\section{References}

Ali MH, Suleiman N, Khalid N, Tan KH, Tseng ML, Kumar M. 2021. Supply chain resilience reactive strategies for food SMEs in coping to COVID-19 crisis. Trends in food science \& technology, 109: 94-102.

Angelos G, Dockter AG, Gachabayov M, Latifi R, Bergamaschi R. 2020. Emergency Colorectal Surgery in a COVID-19 Pandemic Epicenter. Surgical technology international, 14: 36.

Buttell F, Ferreira RJ. 2020. The hidden disaster of COVID-19: Intimate partner violence. Psychological trauma: theory, research, practice, and policy, 12(S1): S197.

Cappelli A, Cini E. 2020. Will the COVID-19 pandemic make us reconsiders the relevance of short food supply chains and local productions?. Trends in Food Science \& Technology, 99: 566-567.

Deaton BJ, Deaton BJ. 2020. Food security and Canada's agricultural system challenged by COVID-19. Canadian Journal of Agricultural Economics, 68(2): 143-149.

Galanakis CM. 2020. The food systems in the era of the coronavirus (COVID-19) pandemic crisis. Foods, 9(4): 10.

Han J, Zhang X, He S, Jia P. 2021. Can the coronavirus disease be transmitted from food? A review of evidence, risks, policies and knowledge gaps. Environmental Chemistry Letters, 19(1): 5-16.

Han S, Roy PK, Hossain MI, Byun KH, Choi C, Ha SD. 2021. COVID-19 pandemic crisis and food safety: Implications and inactivation strategies. Trends in food science \& technology, 109: 25-36.

Khan AI, Shah JL, Bhat MM. 2020. CoroNet: A deep neural network for detection and diagnosis of COVID-19 from chest $\mathrm{x}$-ray images. Computer Methods and Programs in Biomedicine, 196: 105581.

Liu PP, Yang MJ, Zhao X et al. 2020. Cold-chain transportation in the frozen food industry may have caused a recurrence of COVID-19 cases in destination: Successful isolation of SARSCoV- 2 virus from the imported frozen cod package surface. Biosafety and Health, 2(4): 199-201.

Love DC, Allison EH, Asche F et al. 2021. Emerging COVID19 impacts, responses, and lessons for building resilience in the seafood system. Global Food Security, 2021. 28: 100494.

Olaimat AN, Shahbaz HM, Fatima N, Munir S, Holley RA. 2020. Food safety during and after the era of COVID-19 pandemic. Frontiers in Microbiology, 11(4): 1854.

Pang X, Ren L, Wu S, Ma W, Yang J, Di L, Li J, Xiao Y, Kang L, Du S, Du J, Wang J, Li G, Zhai S, Chen L, Zhou W, Lai S, Gao L, Pan Y, Wang Q, Li M, Wang J, Huang Y, Wang J. 2021. Cold-chain food contamination as the possible origin of COVID-19 resurgence in Beijing. National Science Review, 7(12): 1861-1864.

Shahbaz M, Bilal M, Moiz A, Zubair S, Iqbal HM. 2020. Food safety and COVID-19: precautionary measures to limit the spread of coronavirus at food service and retail sector. Journal of Pure and Applied Microbiology, 14(suppl 1): 749-56. 
Rizou M, Galanakis IM, Aldawoud TMS, Galanakis CM. 2020. Safety of foods, food supply chain and environment within the COVID-19 pandemic. Trends in Food Science \& Technology, 102: 293-299.
Selamoglu M. 2021. Importance of the cold chain logistics in the marketing process of aquatic products: An update study. Journal of Survey in Fisheries Sciences, 8(1): 25-29. 